Historia Slavorum Occidentis

2021, nr 4 (31)

ISSN 2084-1213

DOI: $10.15804 /$ hso210411

Marzena Matla (Poznań)

ORCID: 0000-0002-7711-5426

\title{
Nieustająca dyskusja o Słowianach i „idei słowiańskiej”. Książka Eduarda Mühle Słowianie. Rzeczywistość i fikcja wspólnoty: VI-XV wiek, tłumaczenie Joanna Janicka, Warszawa 2020, Wydawnictwo PWN, ss. 473
}

Zagadnienia pochodzenia Słowian i ich pierwotnej wspólnoty, specyfiki kultury i organizacji świata słowiańskiego oraz roli „idei słowiańskiej” w funkcjonowaniu wspólnot politycznych stworzonych przez poszczególne słowiańskie etnosy, żywo dyskutowane w historiografii minionego stulecia, nie tracą na atrakcyjności również w początkach wieku XXI ${ }^{1}$. Kolejnym na to dowodem jest wydana nakładem Wydawnictwa PWN książka znakomitego niemieckiego mediewisty Eduarda Mühle-

1 Tylko tytułem przykładu wymieńmy publikacje: Stowianie, Słowiańszczyzna - pojęcia i rzeczywistość dawniej i dziś, red. K. Handke, Warszawa 2002; Slovanství ve středoevropském prostoru: iluze, deziluze a realita. Pardubická konference (22.-24. dubna 2004), red. D. Hrodek, Praha 2004; Archeologia o początkach Stowian: materiaty z konferencji, Kraków, 19-21 listopada 2001, red. P. Kaczanowski, M. Parczewski, Kraków 2005; Nie-Stowianie o początkach Słowian, red. P. Urbańczyk, Poznań-Warszawa 2006; D. Leśniewska, Kým byli Slované pro naše předky?: kořeny „slovanské myšlenky” v české a polské historiografii před polovinou 18. století, Studia Mediaevalia Pragensia 11 (2012), s. 227-263; Stowianie - idea i rzeczywistość. Zbiór studiów, red. K.A. Makowski, M. Saczyńska, Poznań 2013; F. Curta, Slavs in the Making: History, Linguistics, and Archaeology in Eastern Europe (ca. 500-ca. 700), London 2020; T. Jasiński, The Slavs' Ancestral Homeland, Poznań 2021. 
go, opublikowana w tym samym roku w języku niemieckim² ${ }^{2}$, będąca rozwinięciem dotychczasowych badań autora ${ }^{3}$.

Praca pod względem konstrukcyjnym składa się z dziesięciu rozdziałów, podzielonych na dalsze podrozdziały, została opatrzona bibliografią (s. 429-446), pięcioma mapami (s. 423-428), indeksami (osób, geograficznym, etnonimów i związków osób, s. 447-473), wykazem skrótów (s. 7-9) i krótką przedmową wprowadzającą dla polskiego czytelnika (s. 11-12).

Niewątpliwie E. Mühle postawił sobie ambitne zadanie, nadając swojej pracy szerokie ramy chronologiczne i terytorialne, obejmujące Słowiańszczyznę Południową, Zachodnią i Wschodnią w średniowieczu, łącząc w swoim wywodzie analizę źródeł pisanych i najnowsze ustalenia archeologii. Wprowadzenie do tematu przynoszą dwa pierwsze rozdziały: I. „Prolog: Wyobrażenie Słowian w nowożytności” (s. 13-43) i II. „Przedmiot rozważań” (s. 45-49). W „Prologu” Autor, wychodząc od mowy pochwalnej słowiańszczyzny dominikańskiego mnicha i profesora teologii Vinko Pribojevicia (1525 r.), którego określa mianem „inspiratora nowoczesnej idei słowiańskiej" (s. 14), przybliża rodzące się w dobie nowożytnej zainteresowanie Europy Zachodniej ludami i językami słowiańskimi, dalszy rozwój idei „wspólnoty słowiańskiej” w krajach słowiańskich oraz jej rolę w formowaniu się nowożytnych narodów słowiańskich. Zaznacza, że jej przejęcie przez słowiańskich intelektualistów, początkowo mające funkcję „wspierania wspólnoty językowej i kulturowej”, ustępuje z czasem nowym potrzebom odrębności w służbie wspierania „indywidualnego przebudzenia narodowego" (s. 21) wśród Słowaków, Czechów, Słowian południowych i innych partykularnych interesów. Kolejnym wątkiem jest wpływ idei panslawistycznych na formowanie i umacnianie niemieckich tendencji antysłowiańskich i kreowanie wizji „zagrożenia słowiańskiego”, podrzędności Słowian i konieczności ich cywilizowania, a co za tym idzie, niemieckiego prawa do ekspansji. Ostatnim elementem rozważań jest obecność idei słowiańskiej od doby stalinowskiej (i sowieckiego panslawizmu) po schyłek XX w. Rozdział drugi ma charakter metodologiczny. Autor definiuje tu podmiot swoich refleksji, tj. odpowiedź na pytanie, czy Słowianie i słowiańskość w średniowieczu to rzeczywistość czy też „konstrukt”, „pojęcie abstrakcyjne”, a zatem „w jakim stopniu konstrukcja lub wyobrażenie średniowiecznych «Słowian» nastąpiło już w źródłach im współczesnych,

2 E. Mühle, Die Slawen im Mittelalter zwischen Idee und Wirklichkeit, Böhlau Verlag, Wien-Köln-Weimar 2020, ss. 504. Recenzja tej pracy zob. J. Strzelczyk, Roczn. Hist. 86 (2020), s. 281-282.

3 M.in. E. Mühle, Die Slaven im Mittelalter, Berlin 2016; tenże, Die Slaven, München 2017. 
a jeśli faktycznie tak się stało, to ze względu na czyje interesy i w jakich intencjach historyczno-politycznych” (s. 46); idąc dalej „czy da się w ogóle jeszcze odszukać historyczną rzeczywistość, a jeśli tak, to jakie zjawiska etniczne, społeczne, polityczne i kulturalne można sensownie określić jako «Słowian» albo «słowiańskie»?” (s. 46).Zamierzeniem Autora jest więc z jednej strony pokazanie traktowania „Słowian” jako „kulturowego konstruktu i ich historyczno-polityczną instrumentalizację”, z drugiej zaś analiza realnych struktur historycznych, które możemy łączyć ze „Słowianami” w średniowieczu (s. 47). Temu celowi podporządkowana jest konstrukcja pracy i dalsze rozdziały, do których stanowi on wprowadzenie.

Kolejny, trzeci rozdział - „Odkrycie Słowian we wczesnym średniowieczu” (s. 51-83) - przynosi trzy perspektywy owego „odkrywania” w VI-IX w.: najwcześniejszą, bizantyńską, to bowiem Bizancjum pierwsze musiało stawić czoła wojownikom i osadnikom słowiańskim, poczynając od VI w., dalej zachodnioeuropejską oraz orientalną, arabską. Autor wskazuje, że pojęcie „Słowianie” nie odnosiło się do jakiejś „wielkiej wspólnoty słowiańskiej, etnicznej czy politycznej”, ale służyło określaniu różnych grup ludności słowiańskojęzycznej, jak też podkreślaniu ich obcości i barbarzyńskości. Konstatuje przy tym, że o ile wiedza źródeł bizantyńskich i zachodnich, wynikająca zwykle $\mathrm{z}$ różnych konfliktów, relacji politycznych, osadnictwa słowiańskiego - ograniczona jednak zwykle do własnych obszarów czy bliższego sąsiedztwa - była nieco dokładniejsza, o tyle wyobrażenia źródeł arabskich są dość „niewyraźne”.

Kolejny, czwarty rozdział („Świat wczesnosłowiański”, s. 85-131) służy ukazaniu materialnej i duchowej kultury słowiańskiej, gospodarski, kwestii stratygrafii społecznej i organizacji, a w istocie również odpowiedzi na pytanie, czy mamy do czynienia z jednorodną kulturą słowiańską na różnych obszarach słowiańskich, której obraz rozpoznawała i kreowała archeologia słowiańska minionych dziesięcioleci (często jako emanację słowiańskiej etniczności). Podkreślając problemy z jednoznaczną chronologią znalezisk, niezadowalający stopień przebadania stanowisk wczesnosłowiańskich i problematyczny stan dokumentacji i jej publikacji (s. 93 n.), uniemożliwiające stworzenie pełnego obrazu, zwraca uwagę na odmienności owej kultury na różnych słowiańskich obszarach, chociażby na przykładzie osad czy budownictwa mieszkalnego. Pozwala mu to podważać traktowanie poszczególnych elementów kultury materialnej jako wyrazu przynależności do określonej grupy etnicznej (s. 102) - przeciwnie, to warunki geograficzne czy klimatyczne, adaptacja do miejscowych warunków bytowania, nie zaś etniczna przynależność, bywały decydujące.

Omówienie najstarszych słowiańskich zorganizowanych wspólnot politycznych zaczyna rozdział piąty pt. „Pierwsze słowiańskie władztwa (regna)” (s. 133-166), 
w którym uwzględniono twory powstałe w VIII-IX w., a więc państwo Protobułgarów, Karantan, Stare Morawy. Jednocześnie Autor podważa tradycję Konstantyna Porfirogenety o wczesnym powstaniu państw Chorwatów i Serbów, odnosząc owe legendarne początki raczej do pierwszej połowy IX w. (s. 146 n.). Kolejnemu etapowi tworzenia się państw i narodów słowiańskich w IX-XII w. (a nawet wykraczając w wiek XIII) poświęcono - najobszerniejszy - rozdział szósty zatytułowany „Słowianie w procesie kształtowania średniowiecznych nationes" (s. 167-282). Inicjuje go Bułgaria, tj. państwo Protobułgarów, w procesie asymilacji elit tureckich z miejscową ludnością słowiańską, dalej Czechy, Chorwacja, Ruś Kijowska, Polska, Serbia. Przedstawieniu okoliczności powstania, rozbudowy, przemian społeczno-religijnych i formowania się średniowiecznych nationes towarzyszy analiza kwestii pojawiania się wątku „słowiańskiego” / „wspólnoty słowiańskiej” we wczesnych źródłach pisanych na poszczególnych obszarach (tj. znaczenie terminu „Słowianie”, „słowiańskość”, „ziemia słowiańska”) i ocena jego roli w kształtowaniu się owych wczesnych „narodów”, która zwykle brzmi negatywnie. Autor konstatuje, że nie odgrywały one większej roli w procesie budowy ich tożsamości, zwracając uwagę na inne czynniki: dynastia, obszar, lokalni święci, wrogość wobec obcych. „Słowiańskość”, acz w różnym stopniu obecna i używana, była atrybutem postrzegania zewnętrznego, bywała nawet pojęciem pejoratywnym w odniesieniu do swoich czy sąsiadów, np. w kontekście życia „poza Kościołem katolickim” (s. 269). „Idea słowiańska” pojawia się w XII w. jedynie na Rusi - Powieść lat minionych (s. 243-248) - i na Bałkanach, w księstwie Dukli (Latopis popa Dukljanina, s. 320-326), dotyczy jednak określonego obszaru (nie słowiańskiej całości), służąc politycznym potrzebom legitymizacji władzy. Tu warto jedynie zaznaczyć, że przedstawiony obraz formowania się słowiańskich państwowości może wydawać się czytelnikowi w niektórych momentach nieco spłaszczony, zwykle są to bowiem, wobec skąpej ilości źródeł, kwestie żywo dyskutowane w lokalnych historiografiach, niemniej przy tak szerokim ujęciu tematu wydaje się to nieuniknione. Zapewne można by też dyskutować nad niektórymi jednostkowymi zagadnieniami - przykładowo dość kontrowersyjna kwestia zasięgu słowiańskiego piśmiennictwa w Czechach i potencjalnych ośrodków kultury słowiańskiej ${ }^{4}$ - jednak

4 Por. przykładowo D. Kalhous, Slovanské písemnictví a liturgie 10. a 11. věku, Český časopis historický 108 (2010), č. 1, s. 1-33; w kwestii innych ośrodków - A. Pleszczyński, Znaczenie polityczne i ideowe liturgii słowiańskiej $w$ Czechach we wcześniejszym średniowieczu, [w:] Środkowoeuropejskie dziedzictwo cyrylo-metodiańskie, red. A. Barciak, Katowice 1999, s. 153-164 . 
nie zmieni to zasadnych wniosków Autora ${ }^{5}$. E. Mühle nie pominął w swych rozważaniach również tych wspólnot słowiańskich, które w procesach państwotwórczych nie odniosły sukcesu (rozdział siódmy pt. „Przerwane procesy powstawania słowiańskich państw i kształtowania nationes", s. 283-328), a zatem Słowian połabskich i bałtyckich, Pomorzan oraz części Słowian bałkańskich (Naretan, Zahumljan, Trawunian, Kanalitów, szerzej zaś Dukljan, Bośnian).

Obok prezentowanego dotychczas spojrzenia „wewnętrznego” pojawia się też ponownie dalszy etap zewnętrznego postrzegania świata słowiańskiego (rozdział ósmy pt. „Słowianie w średniowiecznym niesłowiańskim obrazie świata”, s. 329-359) w źródłach bizantyńskich, arabsko-orientalnych i zachodnioeuropejskich (łacińskich), poczynając od około X w. Autor konstatuje w nich zbieżny proces - wraz z lepszym poznawaniem świata ludów słowiańskich i kształtowaniem się wczesnych państw słowiańskich również w źródłach tych ogólne pojęcie „Słowian” ustępuje konkretnym nazwom własnym, geograficznym i etnograficznym, czasem nazewnictwu za pośrednictwem władców. W mniejszym stopniu obszary te są traktowane jako niezróżnicowana całość „słowiańska”, pojęcie zaś „Słowianie” służy już raczej w charakterze negatywnego stereotypu.

Rozdział dziewiąty, noszący tytuł „Koncepcje wspólnoty słowiańskiej w późnym średniowieczu” (s. 361-412), wprowadza w nowy etap funkcjonowania „idei słowiańskiej”. E. Mühle wychodzi tu od źródeł z obszaru późnośredniowiecznych Czech (od tzw. manifestu Przemysła Ottokara II, przez Kronikę Zbrasławska, kroniki doby Karola IV, zwłaszcza Pulkavy, po dobę husycką), przez źródła z ziem polskich (Kronika Dzierzwy i Kroniki książąt polskich, Kronika Wielkopolska, w której widzi właściwy wyraz „idei słowiańskiej”, dzieło Długosza), księstwa Meklemburgii i Pomorza (np. Protocollum z 1347 r., wierszowana kronika Ernsta von Kirchenberga), kończąc na Europie Południowo-Wschodniej i Rusi Kijowskiej oraz Moskiewskiej. Na tej podstawie konstatuje instrumentalizację „idei słowiańskiej” do celów polityki historycznej, legitymizacji władzy i uzasadniania partykularnych interesów panujących władców w Europie Środkowej. Zwłaszcza na dworze Karola IV „ideę słowiańską" uczyniono narzędziem legitymizacji władzy (s. 365), choć sięgnęli do niej także husyci (s. 376 n.). Z kolei w Polsce to „Janko z Czarnkowa wymyślił wspólnotę słowiańską" (s. 381). Inaczej jest na Bałkanach, tj. w drugim państwie bułgarskim czy w Serbii, gdzie wizja „wspólnoty słowiańskiej” nie pojawia się i nie jest wykorzy-

5 Przy okazji „,czeskich aspektów” zwróćmy uwagę na drobną nieścisłość - „młody czeski możny, który wolał uprowadzić córkę bawarskiego hrabiego" z powodu pogardy Niemców dla Słowian w opowieści Kosmasa (ks. I, 40) (s. 212 n.) to w istocie Brzetysław Przemyślida. 
stywana (s. 397, 400 n.), z kolei w Bośni mogła zaistnieć w XV w. tylko sporadycznie i utylitarnie (s. 406 n.). Określenie „Słowianie” zastępowały tu nazwy własne poszczególnych ludów. Również na Rusi wariant „idei słowiańskiej” z Powieści lat minionych przestał oddziaływać i nie miał znaczenia dla formowania regionalnych tożsamości (s. 411). Nieco odmienna sytuacja wystąpiła w wielojęzykowej i wielokulturowej Chorwacji, gdzie w średniowieczu stale obecne były pojęcia „Słowianie”, „słowiański”, jednak na określenie części miejscowej ludności, wiejskiej, w „celach pragmatyczno-praktycznych”, elity zaś postrzegały się jako Chorwaci (s. 408). Niemniej to tu, gdzie nadal pielęgnowano w części Kościoła dziedzictwo cyrylo-metodiańskie, powstały sprzyjające warunki, w których „wczesny humanizm [ ... miał wykształcić pierwszy nowożytny wariant «idei słowiańskiej»” (s. 410).

Podsumowanie ustaleń przynosi ostatni, rozdział dziesiąty („Epilog: Wyobrażenie Słowian w średniowieczu”, s. 413-420). E. Mühle stwierdza m.in., że pierwotnie termin Sclaveni/Sclavi(ni) (który uważa za nazwę własną owych pierwszych grup słowiańskich, nie bizantyński wytwór) odnosił się jedynie do słowiańskojęzycznych grup zamieszkujących na Bałkanach, potem zaś został rozszerzony na grupy pokrewne językowo poza tym obszarem, w państwach Merowingów, Longobardów i Karolingów (s. 415). Dalej podkreśla brak istnienia poczucia wspólnoty słowiańskiej czy wykształcenia specyficznej tożsamości słowiańskiej w średniowieczu - „«Słowianie» stanowili zatem [...] przede wszystkim imagined community, «wspólnotę wyobrażoną», którą od czasu do czasu, w konkretnych sytuacjach inscenizowano i instrumentalizowano choć zapewne nie tylko - w celach legitymizacyjnych” (s. 420).

Podsumowując, trzeba stwierdzić, że recenzowana książka stanowi ważną pozycję w dotychczasowej dyskusji nad dziejami Słowiańszczyzny i „idei słowiańskiej”. Godna uznania jest niewątpliwie erudycja Autora, krytycyzm, szeroka postawa źródłowa, uwzględnienie najnowszych badań z poszczególnych obszarów, w tym badań archeologicznych, a także literatury przedmiotu w językach słowiańskich. Niewątpliwie praca ta doskonale posłuży dalszemu rozwojowi dyskusji nad problematyką słowiańską.

\section{Bibliografia}

Archeologia o początkach Słowian: materiały z konferencji, Kraków, 19-21 listopada 2001, red. P. Kaczanowski, M. Parczewski, Kraków 2005. Curta F., Slavs in the Making: History, Linguistics, and Archaeology in Eastern Europe (ca. 500-ca. 700), London 2020. 
Jasiński T., The Slavs' Ancestral Homeland, Poznań 2021.

Kalhous D., Slovanské písemnictví a liturgie 10. a 11. věku, Český časopis historický 108 (2010), č. 1, s. 1-33.

Leśniewska D., Kým byli Slované pro naše předky?: kořeny „slovanské myšlenky” $v$ české a polské historiografii před polovinou 18. století, Studia Mediaevalia Pragensia 11 (2012), s. 227-263.

Mühle E., Die Slaven, München 2017.

Mühle E., Die Slaven im Mittelalter, Berlin 2016.

Mühle E., Die Slawen im Mittelalter zwischen Idee und Wirklichkeit, Böhlau Verlag, Wien-Köln-Weimar 2020.

Nie-Słowianie o początkach Słowian, red. P. Urbańczyk, Poznań-Warszawa 2006 Pleszczyński A., Znaczenie polityczne i ideowe liturgii słowiańskiej w Czechach we wcześniejszym średniowieczu, [w: Środkowoeuropejskie dziedzictwo cyrilo-metodiańskie, red. A. Barciak, Katowice 1999, s. 153-164.

Slovanství ve středoevropském prostoru: iluze, deziluze a realita. Pardubická konference (22.-24. dubna 2004), red. D. Hrodek, Praha 2004.

Stowianie - idea i rzeczywistość. Zbiór studiów, red. K.A. Makowski, M. Saczyńska, Poznań 2013.

Stowianie, Stowiańszczyzna - pojęcia i rzeczywistość dawniej i dziś, red. K. Handke, Warszawa 2002.

StrzelczykJ., Recenzja Eduard Mühle, Die Slawen im Mittelalter zwischen Idee und Wirklichkeit, Böhlau Verlag, Wien-Köln-Weimar 2020, Roczniki Historyczne 86 (2020), s. 281-282.

Nadesłany: 31 V 2021

Zaakceptowany: 30 VI 2021

Dr hab. Marzena Matla, prof. UAM

Uniwersytet im. Adama Mickiewicza w Poznaniu

Wydział Historii

ul. Uniwersytetu Poznańskiego 7

61-614 Poznań

e-mail: mmatlam@amu.edu.pl 